\title{
Relationship Between Body Mass Index of Pregnant Women And Birth Weight of Babies With The Incidence of Bgm In Infants
}

\section{Nyna Puspita Ningrum}

Midwifery Lecturer at the Faculty of Health Science, PGRI Adi Buana University, Surabaya

Email:

nyna@unipasby.ac.id

Received: October 5, 2020

Accepted : November 27, 2020

Published : November 30, 2020
Poor nutritional conditions in infants that occur in a long time can affect the growth process of infants, the risk of immune system disorders, and the risk of infection that can end in death. BGM conditions that are not handled properly can run the risk of being stunted.

The purpose of this study was to analyze the relationship between the body mass index of pregnant women and birth weight of babies with the incidence of BGM in infants.

This research method is quantitative analytic research with correlative study design approach. The populations were all infants and mothers of children under five in Siwalankerto village with total of 47 peoples; the sampling technique used was purposive sampling in accordance with the inclusion and exclusion criteria, so as to get 40 people. Data was tested for validity using the product moment validity test method.

Based on the results obtained with the chi square reliability test value of $\mathrm{X}$ count $=14.89$ which is greater than the value of $\mathrm{x}$ table $=7.815$ (for $\mathrm{N}=40$ respondents). So it can be concluded that there is a relationship between body mass index of pregnant women and birth weight of babies with the incidence of BGM in infants.

Suggestions for health workers is to increase preventive efforts through approaches and counseling to the community in order to minimize the occurrence of malnutrition in pregnant women which can have an impact on children's health in the future.

Keywords: Body mass index, birth weight, pregnant women

Copyright (C) 2020 IIK STRADA Indonesia All right reserved.

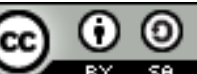

This is an open-acces article distributed under the terms of the Creative Commons Attribution-ShareAlike 4.0 International License.

\section{INTRODUCTION}

Fulfillment of adequate nutrition from an early age is a picture of a person's nutritional status. Poor nutritional status or weight below the Red Line (BGM) is one of the malnutrition problems that need more attention and immediate treatment from the Indonesian government. Under nutrition conditions in infants that occur in a long time can affect the growth process of infants, immune system disorders, and the risk of infection that can end in death (Hong et al, 2006). BGM conditions that are not handled properly can run the risk of being stunted. Research results in 2013 that Stunting in Indonesia was recorded at 37.2\%, which means experienced a surge from 2010, which amounted to $35.6 \%$ (Balibangkes, 2013).

The nutritional status of pregnant women can be measured from the body mass index of pregnant women. The results of a study from Kusin and Kardjati in 1994 concluded that pregnant women who experience poor nutrition will affect the growth of the baby and continue until the child is 2 years old. According to Karima and Achmadi in 2012, mothers who experience malnutrition will affect the quality of the placenta so that the distribution of nutrients to the fetus is reduced, resulting in stunted fetal growth. Pregnant women with less nutritional status are more at risk of giving birth to 
babies with Low Birth Weight four times greater than pregnant women with good nutritional status, this will also affect the growth disorders of children at a later stage (Ariyani et al, 2012).

Based on the above explanation, researchers are interested in conducting a study of the relationship between body mass index of pregnant women and birth weight of babies with the incidence of BGM in infants in Siwalankerto district Surabaya.

\section{MATERIALS AND METHODS}

This research is a quantitative analytical study using research methods conducted with the aim of analyzing the relationship of BMI of pregnant women, birth weight of babies with the incidence of BGM in infants. Analysis is based on case control, which analyzes causality in a causal logic with reverse logic, determines the results and continues with the identification of the cause.

The independent variables in this study are BBL data and BMI data. And the dependent variable is BGM observation. The populations and sample in this study were infants and mothers in Siwalankerto district with number of 40 respondents that are detected as BGM infants. In this study the sampling technique used purposive sampling technique.

Research data collection tools and methods were carried out by means of observing subject groups to determine cause and effect, to determine the relationship or relationship between independent variables and the dependent variable, in order to determine the relationship of BMI of pregnant women and birth weight with the incidence of BGM in infants.

In this study the data was tested for validity using the product moment validity test method. To proves the validity of the analysis of the relationship between BMI of pregnant women and the weight of newborns with the incidence of BGM in infants. The reference used is $r$ table = 0.3120 ( $\mathrm{N}=40$ respondents). Reliability analysis is carried out after the data is collected. Data in the form of normal variables are then examined and tested with Chi Square with a 0.05 correlation level (obtained $\mathrm{x}$ table value $=7.815$ ). The location of the study was conducted at the local community health for infants (Posyandu Balita) in Siwalankerto District. The study was conducted from April to May 2020.

\section{RESULTS}

The results of the research have been achieved in research conducted at the local community health for infants (Posyandu Balita) in Siwalankerto District in April - May 2020. Respondents who participated in this study as many as 47 people and appropriate inclusion criteria as much as 40 people.

Table 1. Distribution of respondents by body mass index of pregnant women

\begin{tabular}{lccc}
\hline No & Body Mass Index for Pregnant Women & $\mathrm{N}$ & $\%$ \\
\hline 1 & Less than $\left(<18.5 \mathrm{~kg} / \mathrm{m}^{2}\right)$ & 20 & 50.00 \\
2 & Normal $\left(<18.5\right.$ to $\left.24.9 \mathrm{~kg} / \mathrm{m}^{2}\right)$ & 20 & 50.00 \\
\hline Total & 40 & 100.00 \\
\hline In presenting the above table shows that by criteria of body mass & index of pregnant \\
women, with fewer criterions as much as 20 respondents $(50.00 \%)$. And normal criterions as much \\
as 20 respondents (50.00\%).
\end{tabular}

Table 2. Distribution of Respondents by Birth Weight

\begin{tabular}{cccc}
\hline No & Baby's Weight & $\mathrm{N}$ & $\%$ \\
\hline 1 & $<2.5 \mathrm{~kg}$ & 16 & 40.00 \\
2 & $2.5-3 \mathrm{Kg}$ & 24 & 60.00 \\
Total & & 40 & 100.00 \\
\hline
\end{tabular}

In the presentation of the table above shows that based on the birth weight of babies $<2.5 \mathrm{~kg}$ as many as 16 respondents $(40.00 \%)$. Range $2.5-3 \mathrm{~kg}$ as many as 24 respondents $(60.00 \%)$.

Table 3. Distribution of Respondents by BGM Status in Infants

\begin{tabular}{cccc}
\hline No & BGM Status in Infants & N & $\%$ \\
\hline
\end{tabular}




\begin{tabular}{cccc}
\hline 1 & Non - BGM & 26 & 65.00 \\
2 & BGM & 14 & 35.00 \\
\hline Total & & 48 & 100.00 \\
\hline
\end{tabular}

Infants respondents with a status of Non-BGM as much as 26 respondents $(65.00 \%)$, and the status of BGM as much as 14 respondents $(35.00 \%)$.

Table 4. Cross Tabulation "Association of body mass index of pregnant women and birth weight in infants with an incidence BGM"

\begin{tabular}{cccccccc}
\hline No & $\begin{array}{c}\text { BGM status } \\
\text { Respondents }\end{array}$ & Non-BGM & $\%$ & BGM & $\%$ & total & $(\%)$ \\
\hline 1 & BMI Normal / Non-LBW & 13 & 32.50 & 0 & 0.00 & 13 & 32.50 \\
2 & Normal BMI / LBW & 5 & 12.50 & 2 & 5.00 & 7 & 17.50 \\
3 & Non-Normal / Non-LBW BMI & 6 & 3.00 & 5 & 12.50 & 11 & 27.50 \\
4 & Non-Normal BMI / LBW & 2 & 5.00 & 7 & 17.50 & 9 & 22.50 \\
\hline & Total & 26 & 65.00 & 14 & 35.00 & 40 & 100.00 \\
\hline
\end{tabular}

Based on the above table which shows that infants with BGM status were as many as 2 infants $(5.00 \%)$ with respondents who were pregnant with normal BMI and babies born low, infants with BGM status were 5 infants $(12.50 \%)$ with respondents during pregnancy were not normal IMT and babies were not born low, and infants with BGM status as many as 7 infants (17.50\%) with respondents during pregnancy IMT mothers were less normal and babies were born low.

\section{DISCUSSION}

Based on the results of research that has been conducted on infants and mothers in Siwalankerto district number of 40 respondents statistical result in getting the value of the reliability test chi square of $\mathrm{x}$ count $=14.89$ which is greater than the value of $\mathrm{x}$ table $=7.815$. It can be concluded that there is a relationship between body mass index of pregnant women and birth weight of babies with the incidence of BGM in infants (respondents). The results of this study will not be absolute, some external factors that can cause infants with BGM such as parenting patterns of life, living conditions for toddler families, consumption of toddler nutrition, parents' level of awareness of children's nutritional adequacy can be further investigated as a basis for solving problems health in children in Indonesia.

This study is in line with the results of research conducted by Sukmawati, et al in 2017 in Maros Regency which states that there is a significant relationship between the nutritional statuses of pregnant women as measured through LILA with the incidence of stunting in infants. The growth and development of the fetus in the womb is strongly influenced by the nutritional intake of pregnant women. The nutritional status of the mother during pregnancy if at normal values, it is most likely that the fetus will be born in a healthy condition, full term, and in normal condition (Andriani and Bambang, 2016).

Infants are the age group of children who are in the age range of 0-5 years, where this period is the most vulnerable to the lack of nutritional intake according to needs. Nutrition that adequate and quality health and will support their growth and development process so as to minimize the risk of malnutrition that causes the toddler suffered BGM (Lassi, 2017). At the age of growth and development, weight becomes one of the important indicators of children's health and development. The research menu of Uki Nengsih in 2015 in Bandung stated that there was a relationship between LBW birth history and the growth of children under five years old. According to Pitkin, 2007 babies with a history of LBW will have a long-term impact on the process of growth and development because it is associated with central nervous system disorders and neurological disorders. However, not all babies with LBW birth history will experience growth disturbance.

Based on the findings of the researchers found $5(12.5 \%)$ of 40 respondents had a history of maternal pregnancy with a normal BMI, the baby had LBW but the toddler did not experience BGM. These results are in line with the results of Uki Nengsih research that there are $4(15.7 \%)$ of 24 respondents who have a history of LBW normal growth. This is in accordance with Wiknjosatro's 
theory in 2007 that the prognosis of infants with LBW is seen from the severity or severity of perinatal problems experienced and can be terminated if you get the right treatment.

\section{CONCLUSION}

Research on the relationship between body mass index of pregnant women and birth weight of babies with the occurrence of BGM in Infants in Siwalankerto district obtained a chi square reliability test value of $\mathrm{x}$ count $=14.89$ which is greater than the value of $\mathrm{x}$ table $=7.815$ (for $\mathrm{N}=40$ respondents) so that conclusions can be drawn. There is a relationship between body mass index of pregnant women and birth weight of babies with the incidence of BGM in infants (respondents).

\section{ACKNOWLEDGMENTS}

The author is thankful for respondents for their valuable information and its awareness to participate in this research.

\section{CONFLICTS OF INTEREST}

The author declares that they have no conflict of interest

\section{REFERENCES}

Adriani, M., \& Wirjatmadi, B. (2016). The role of nutrition in the life cycle. Jakarta: Group of Kencana Prenada Media.

Forsum, E., \& Löf, M. (2007). Energy metabolism during human pregnancy. Annu. Rev. Nutr., 27, 277-292.

Lassi, Z. S., Salam, R. A., Haider, B. A., \& Bhutta, Z. A. (2013). Folic acid supplementation during pregnancy for maternal health and pregnancy outcomes. Cochrane Database of Systematic Reviews, (3). https://doi.org/10.1002/14651858.CD006896.pub2

Meyers, L. D., Hellwig, J. P., \& Otten, J. J. (Eds.). (2006). Dietary reference intakes: the essential guide to nutrient requirements. National Academies Press.

Notoatmodjo, S. (2010). Health Promotion Theory and Applications. Jakarta: Rineka Science.

RI Minister of Health Regulation. (2013). Nutrition Adequacy Rate Recommended for the Indonesian Nation. RI Ministry of Health No.57 of 2013, Jakarta

Pitkin, R. M. (2007). Folate and neural tube defects. The American journal of clinical nutrition, 85(1), 285S-288S. https://doi.org/10.1093/ajen/85.1.285S

Sukmadinata, N. S. (2011). The Foundation of the Psychology of the Education Process. Bandung: PT. Teens Rosdakarya.

Trumbo, P., Schlicker, S., Yates, A. A., \& Poos, M.(2012). Food, Nutrition Board of the Institute of Medicine TNA. Dietary reference intakes for energy, carbohydrate, fiber, fat, fatty acids, cholesterol, protein and amino acids, 1621-30.

TNP2K. (2017). 100 Districts/Cities Priority for Intervention of Little Children (STUNTING). Jakarta 